\title{
The Effect of Bank Specific Factors on the Performance of Afriland First Bank in Cameroon
}

\section{Mbella ME* and Magloire AA}

Department of Banking and Finance, Catholic University Institute of Buea, CIUB, Cameroon

\begin{abstract}
This study was out to examine the extent to which bank-specific factors affect the performance of Afriland First Bank. The key internal drivers of Afriland First Bank's profitability identified in this research were: capital adequacy, liquidity management, management efficiency and asset quality. Afriland First Bank was selected out of fourteen commercial banks because during the period of study, it was the only local bank among the top commercial banks in terms of market shares in Cameroon. The researcher extracted data from the consolidated financial statements of Afriland First Bank from the period 2009 to 2016 inclusive. With the help of Generalised Methods of Moments, the result showed that capital adequacy, liquidity management and Asset Quality were found to have a significant negative effect on Return on Assets, meanwhile Management Efficiency was found to have significant positive effect on Return on Asset of Afriland First Bank during the period of study. The humble recommendation made to Afriland First Bank is to avoid very risky investments in the future.
\end{abstract}

Keywords: Capital adequacy; Liquidity; Management; Asset quality

\section{Introduction}

World over, commercial banks play an important intermediary role of channelling funds from surplus economic units to deficit economic units. This role ensures that scarce resources are efficiently and effectively allocated among competing users. However, commercial banks can perform this task if they are being able to generate enough income to cover their operational cost. In other words, to effectively perform their intermediation role, commercial banks need to be profitable. The good performance of commercial banks rewards shareholders for their investments and has critical implications for the growth of the banks in particular and economic growth of countries in general. On the other hand, the poor performance of commercial banks leads to bank failure, eventual crisis and negative repercussions on economic growth due to contagion effects. This, therefore, suggest that commercial bank performance is a function of a number of factors which could be specific and/or external factors. The performance of commercial banks has thus been of great interest to academic research since the great depression of 1929.

Following the 1929 economic depression, commercial banking activities were separated from investment banking activities by the Glass Steagall act of 1933. This was first to reduce the high risk taking appetite of commercial banks with depositor's money and also to stabilize the performance of both commercial and investment banks [1]. Before the 1986 world economic crisis, Cameroon had one of the best banking system in French - speaking Africa which so far had succeeded in mobilizing private and public sectors deposits. Prior to oil production, the Cameroonian banking sector was dominated by French merchant banks and in the early 80s; American banks also gained interest in the sector. However, the market structure of the banking industry remained unchanged maintaining an oligopolistic structure at the time. Four major Banks played active roles and these were: Société Commerciale de Banque, Société Générale de Banque au Cameroun, Banque Internationale pour l'Afrique Occidentale - Cameroun and Banque Internationale pour le Commerce et l'industrie du Cameroun. These banks had relatively many bank branches.

However, with the up surge of the economic crisis in 1986, a great number of banks with foreign equity holdings, in particular the
American banks, withdrew from Cameroon and some local subsidiary were sold. This led to tight bottlenecks in liquidity and a majority of the commercial banks obviously became insolvent. Many banks such as the National Development Bank were liquidated and/or acquired between 1989 and 1992 [2]. This forced the government of Cameroon to put in place a structural adjustment programme as banks are known to be 'too big to fail'. Despite these far reaching reforms, the banking system continued operating in a difficult context during the 1993/1994 financial year. In 1994/95, of the eight Commercial banks that existed in the country, only three among which were, SCB-Credit Lyonais, Amity Bank and the Caisse Commune d'Epargne et D'Investissement (CCEI) presently known as Afriland First Bank presented convincing balance sheets in order to strengthen control and regulation in the financial system, the Banking Commission for Central Africa was created in 1990 acting as a regional body in the CEMAC zone.

The low level of Africa's financial integration meant that African economies were relatively isolated from the immediate impact of the financial crisis. This was because Africa's external financing (Bond issues, stocks and private borrowing) was low, representing only $4 \%$ in 2007 of overall issue for emerging economies [3]. African banking assets represented only $0.87 \%$ of global banking assets, compared to $58.15 \%$ for the 15 countries of the Euro zone and $15.09 \%$ for the United States of America. Again, few banks and investment firms in Africa held derivatives backed by sub-prime mortgages [4]. As a member of a globalized world, it was first alleged that Sub-Saharan Africa (SSA) would not be certainly affected by the financial crisis because of its marginal representation in the world financial markets as described above.

*Corresponding author: Mukete Emmanuel Mbella, Department of Banking and Finance, Catholic University Institute of Buea, CIUB, Cameroon, Tel: +237233322829; E-mail: mbellamukete@gmail.com

Received September 25, 2017; Accepted November 27, 2017; Published December 072017

Citation: Mbella ME, Magloire AA (2017) The Effect of Bank Specific Factors on the Performance of Afriland First Bank in Cameroon. J Bus Fin Aff 6: 305. doi: 10.4172/2167-0234.1000305

Copyright: (c) 2017 Mbella ME, et al. This is an open-access article distributed under the terms of the Creative Commons Attribution License, which permits unrestricted use, distribution, and reproduction in any medium, provided the original author and source are credited. 
By the end of 2008 and early 2009, the financial crisis that rapidly moved to an economic crisis started having its impacts in Sub-Saharan African countries and it did not avoid Cameroon. Given that nine out of the twelve existing commercial banks in Cameroon were owned by foreigners, Naude ranked Cameroon's vulnerability to the crisis as medium. The aftermath of the crisis indeed left the Cameroon banking sector with a need to improve on its performance. Banking reforms were instituted by the Banking Commission of Central African States. They aimed at promoting financial stability and improving the performance of existing commercial banks by then. These reforms had as specific objectives to awaken the financial sector, reduce the ratio of Non-Performing Loans to Total loans, improve corporate governance, improve liquidity, improve Shareholder's return on investment and encourage healthy competition in the sector. One of such reforms was the recapitalization of all commercial banks by June 2014 [5].

In October 2016, BEAC established that there existed 14 commercial banks in Cameroon with a total number of 252 branches all over the national territory. They include: AFB (40) BAC (12), BICEC (39), CBC (8), Citibank (2), Ecobank (27), SCB-CA (50), SGC (28), SCBC (2), UBC Plc (11), UBA (13), NFC (14), BGFIBank (4), BC-PME (2). Today, Afriland First Bank, Société Générale Cameroun and BICEC lead the banking sector with over $65 \%$ of market shares. Abdul et al. [6], opined that banks which performs well in terms of profitability is able to promote the economic growth of the country and is able to sustain with sudden economic downturns.

According to Rosman et al. [7], banks around the world especially in developing countries are focused on raising their capital adequacy levels to $8 \%$ as required by the Basel committee in order to minimize the risk level of their balance sheets. This is believed will contribute to the long run improvement of banks' performance and prevent massive losses in case of future adverse financial conditions. In Cameroon, the Banking Commission of Central African States (COBAC) ordered all commercial banks to raise their capital levels from XAF FCFA $1,000,000,000$ to XAF FCFA $10,000,000,000$ in order to satisfy the minimum capital adequacy ratio of $8 \%$. Despite the measures taken by the regulatory authorities and commercial banks in Cameroon to minimize their level of exposure to the risk of loses/failure some banks such as the CBC-bank and UBC Plc. still face some difficulties in maintaining a stable financial condition. Others have experienced increasing operating expenses as in the case of Afriland First Bank. This consequently led to a significant fall in the bank's net profit between the years 2010 to 2011 [8]. To remedy the situation of losses just mentioned above, Afriland First Bank's top management strategized for a reduction in operating expenses and an improvement in the quality and variety of products and services to meet up with customers' needs and competition. Nevertheless, the bank still made its highest losses in 2012. All these triggered the researcher to carry out a study to provide answers to the following questions; Does capital adequacy affect the profitability Afriland First Bank in Cameroon? Does management efficiency affect the profitability of Afriland First Bank in Cameroon?

This study has as objective to examine the extent to which bank specific factors affect the performance of Afriland First Bank in Cameroon. This will be done by investigating effects of capital adequacy on the Return on Asset of Afriland First Bank Cameroon; determining the effects of management efficiency on the Return on Asset of Afriland First Bank Cameroon; and the influence of asset quality on the Return on Asset of Afriland First Bank Cameroon. In order to scientifically valid the results of this study hypothesised as:

Ho: Capital adequacy, Management efficiency and Asset Quality has no statistical significant effect on Afriland Bank Performance in Cameroon.

\section{Significance of the study}

The results of the study will provide insights into how the bank specific factors affect the profitability of Afriland First Bank. It will thus enable the top management of Afriland First Bank Cameroon to undertake measures that will place the bank in a position to continually improve on its profitability. The research will equally provide information on the individual determinants of Afriland First Bank's profitability namely capital adequacy, credit risk, asset quality and management efficiency. The elaboration of these determinants will provide detailed information on each factor thus contributing to the body of knowledge.

\section{Literature review}

Bank Specific factors or internal factors are individual bank characteristics which affect the bank's performance. These factors are basically influenced by the internal decisions of the top management and the board of directors. The internal factors identified and analyzed in this study are as stipulated below.

Capital adequacy (CA) refers to the measure of a bank's capital or net worth. It is used to protect customers' deposits, strengthen the soundness of banks, provide a stable resource to absorb losses and promote the stability and efficiency of financial systems of nations around the world by lowering the risk of banks of becoming insolvent. The minimum capital ratio reserve requirement for a bank is set at $8 \%$ as stipulated by the Basel Accord (Basel I) of 1988; $6 \%$ of which must be provided by Tier one capital and the remaining $2 \%$ by Tier two capital. In Cameroon the fully paid-up capital is XAF FCFA 10 000000 000. During the process of winding-up, depositors can only lose their savings if a bank registers a loss that exceeds the amount of capital it possesses. Thus, the higher the bank's capital adequacy ratio, the higher the degree of protection of customers' deposits. In this work, capital adequacy was proxied using the ratio: Shareholders' Equity/ Total Assets. This was because many banks revalue their financial assets more often than companies in other industries that hold fixed assets at a historical cost.

Liquidity management (LM) refers to the ability of the bank to meet maturity liabilities and customers' demand for cash. Thus a bank with high liquidity levels is expected to be less profitable than one with a liquidity level that is lesser. In this work, liquidity management was measured using the ratio: Total Loans/Customers' deposits.

Management Efficiency is one of the key internal factors that determine bank profitability. Poor operating management is the main contributor to poor profitability [9]. In the literature on bank performance, operational expense efficiency is usually used to assess managerial efficiency in banks. Although the relationship between expenditure and profits appears straightforward implying that higher expenses mean lower profits and the opposite, this may not always be the case. The reason is that higher amounts of expenses may be associated with higher volume of banking activities and therefore higher revenues [10]. In this work, Management efficiency will be proxied using the operating ratio: Net Operating Profit/Net Income.

Asset Quality (AQ) is one of the critical areas in determining the overall condition of a bank. The primary factor that affects the overall asset quality of a bank is the quality of its loan portfolio and the credit administration program. This is because loans are the main 
assets which the bank uses to generate a greater portion of the bank's income. However, loans carry the greatest amount of risk to the bank as customers may default payment. A bank with a poor quality of assets (a rating between 3 and 5) is thus expected to be less profitable compared to one which has a better quality of asset (a rating between 1 and 2). This work measured asset quality using the following ratio: Loan Loss Provisions/Total Assets.

Bank performance refers to how well a bank is doing in providing its products and services to customers. The two main aspects of performance include: financial performance (liquidity, solvency, efficiency and profitability) and market competition. This study will concentrate on financial performance which refers to the degree to which financial objectives are being or have been accomplished. Profitability as an indicator of financial performance. This work measured profitability in terms of Return on Assets. It is an indicator of how profitable a bank is relative to its Total Assets. However, not all assets can be used earn income because banks must have cash to satisfy cash withdrawal requests of customers when they fall due. Banks thus hold cash in vaults and inside Automated Teller Machines that earn no interest. This work measured Return on Assets as follows: Net Income/ Average Total Assets.

Magweva [11] carried out a research on Bank specific factors and bank performance in the multi-currency era in Zimbabwe. Using secondary data (obtained from audited year financial statements) from 2009 to 2015 to avoid the effect of structural breaks caused by the suspension of Zimbabwean currency and subsequent introduction of multi-currency regime in 2009. This paper utilized quantitative methodology in ascertaining the relationship between bank internal features and bank performance in Zimbabwe. The results indicated that bank specific indicators were not significant in determining bank performance but rather bank external factors could play a significant role in determining bank performance. He recommended that the Central Bank embark on a softer stance as the level of capital does not significantly affect the return on assets of the firms, though it enhances soundness and stability of the sector.

Mahmud et al. [12] in identifying the bank specific variables that affect the profitability of commercial banks of Bangladesh, used a total of 15 commercial from 2003-2013. The study used return on asset as the dependent variable and bank specific variables like capital adequacy ratio, gearing ratio (risk), liquidity, non-performing loan ratio, operating expense ratio and bank size as independent variables. Prais-Winsten correlated panels corrected standard errors model was employed which removes any autocorrelation and heteroscedasticity problem automatically for the panel data. The results indicated that size, operating expense, gearing ratio and capital were found to be important variables that affect the bank profitability of Bangladesh. Their empirical results suggest that adequate capital, low risk, efficient expense management and rightsizing lead to greater performance and profitability for Bangladeshi bank industry.

Sufian and Habibullah [13] examined the impact of both bank specific and macroeconomic variables that affect profitability of Bangladesh banking industry. The study was conducted on a panel data set consisting 42 Bangladeshi commercial banks. The study used bank specific variables such as bank financial risk, bank operational efficiency, and bank sizes as well as macroeconomic variables such as economic growth are examined to estimate their impact of bank profits. The paper indicates that factors such as loan-deposit ratio, loan-loss provision to total assets, equity capital to total assets, and operating expenses to total assets are significant factors. Bank sizes and macroeconomic variable show no impact on profits.

In the study conducted by Aremu et al. [14] in Nigeria, they found that capital adequacy is negatively related to bank's profitability in both short and long run, they suggest that banks do not utilize or manage their capital efficiently. Furthermore, higher equity-to-asset ratio will reduce after-tax earnings since it will reduce the tax shield provided by the deductibility of interest payments. Wasiuzzaman and Tarmizi [15] also found a negative relationship and they explained that the lower the equity-to-asset ratio, the higher the leverage or debt financing, the higher the bank's profitability. This is because banks are not focus in rising equity to boost profits. Instead, banks prefer to increase leverage or debt financing which ultimately cause higher profits.

Other than that, some researchers have found that there is an insignificant relationship between capital adequacy and bank's profitability. In a research of bank's profitability in Nigeria, Olalekan and Adeyinka [16] found that capital adequacy does not have a significant relationship to the profitability for both domestic and foreign banks.

Obamuyi [17] conducted a study on 20 commercial banks of Nigeria from 2006 to 2012. He employed fixed effect model to determine the relationship of different bank specific and macroeconomic variable. The study reported that bank capital, size, interest income and expense management efficiency and favorable economic conditions contribute to higher bank performance and growth. Abduh and Idrees [18] supported the fact that bank size is positively related to bank profitability. They mentioned that larger bank has greater loan diversification and also greater accessibility to capital markets when compared to small bank.

\section{Theoretical Framework}

The first theory used in this study is the Modern Portfolio Theory (MPT) states that "risk-averse investors construct portfolios based on the maximization of expected returns on the portfolios and the minimization of investment risk". The theory further maintains that "the essential aspect pertaining to the risk of an asset is not the risk of each asset in isolation, but the contribution of each asset to the risk of the aggregate portfolios' (Royal Swedish Academy of Sciences, 1990). The assumptions of the theory include: Investors are rational (they seek to maximize returns while minimizing risk), there is information symmetry, Investors can borrow or lend an unlimited amount of capital at a risk free rate of interest, Markets are perfectly efficient and Markets do not include transaction costs or taxes.

This study was interested in this theory because it explains the relationship between asset portfolio selection (quality) by risk adverse investors (banks) and expected return (profits). Again, the same theory highlights the various systematic and unsystematic risks inherent to a portfolio of assets which thus affect its contribution to overall future earnings. According to the Modern Portfolio Theory, it's possible to construct an efficient frontier which represents the best combination of assets (those producing the maximum expected return for a given risk level) within an investment portfolio as seen (Figure 1).

The theory is however limited as follows: the assumption that investors are rational is contradicted by the well-known investment principle of the higher the risk, the higher the return; In reality, world markets comprise information asymmetry, insider trading, and investors who are simply better informed than others and real 


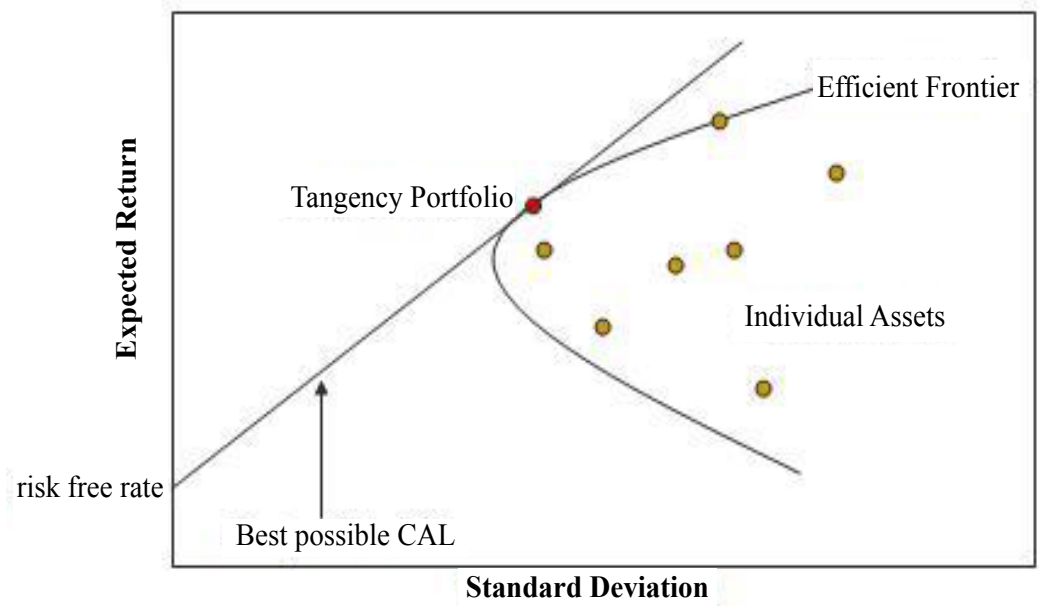

Source: Markowitz portfolio selection (1952).

Figure 1: Markowitz efficient frontier.

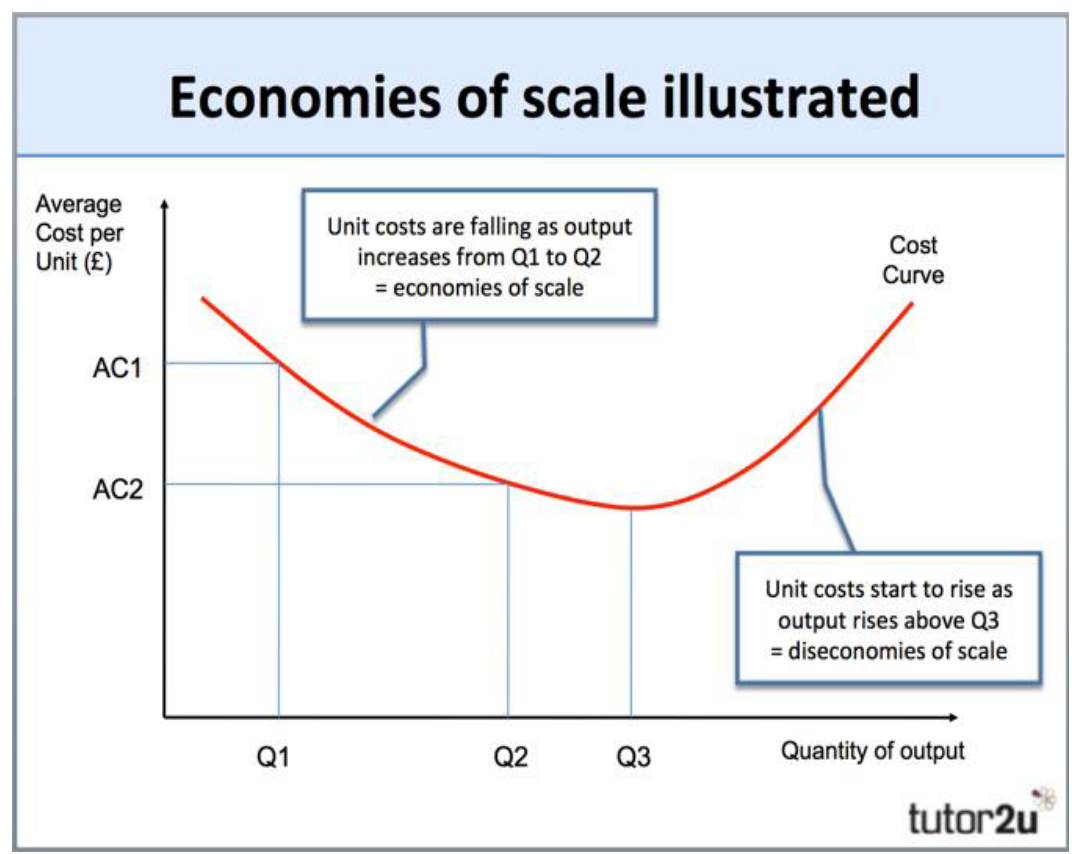

Source: Kusa [21].

Figure 2: An illustration of economies of scale.

investment products are subject to both taxes and transaction costs (administrative costs and direct taxes).

The theory of Economies of Scale suggests that the cost of producing an additional unit of output (marginal cost) of product (good and/or service) decreases as the volume of output (Scale of output) increases'. Therefore, large corporations are able to gain cost advantage when producing more output as their scale of output is increased and average cost per unit is reduced as seen (Figure 2).

In this light, a bank is considered to have achieved economies of scale when it is able provide different ways for consumers to use a particular financial service or product such as cash deposits and transfer of payments at a reduced cost as in the case of Afriland. The theory helps explain how efficient the management of Afriland is by reducing the fix-cost per unit as the bank provides a variety of services to customers as a result of internal growth. The limitations of the theory include: Management problems, maintaining effective communication, divorce of ownership and control and coordinating activities generally across the globe.

The next is the signalling Dividend theory which holds that, "firms that increase significantly dividend payment had a corresponding increase in share prices whereas those firms that omitted or reduced significantly dividend payment had a corresponding decline in share prices". Proponent of this theory suggested that investors prefer dividend to capital gains. The theory assumes that: dividend change announcements are positively correlated with share price reactions and future changes in profits.

The theory asserts that announcement of increased dividend payments by a company gives strong signals about the bright future 
prospects of the company. An announcement of an increase in dividend payout is taken very positively in the market and helps in building a very positive image of the company regarding the growth prospects and stability in the future. Due to information asymmetry (managers knowing more about the bank's future earnings more than shareholders) investors will look for other information such as the bank's dividend policy. Investors can use this knowledge about managers' behavior to inform their decision to buy or sell the bank's stock, bidding the price up in the case of a positive dividend surprise, or selling it down when dividends do not meet expectations. In practice changes in a firm's dividend policy can be observed to have an effect on share prices. That is to say an increase in dividend causes share prices to go up whereas decreases in dividend would pull the share prices down. This pattern forced Stephen Ross to conclude contrary the Miller and Mordigliani model that shareholders do in deed prefer dividend to future capital gains. This study had interest in this theory because it explains the relationship that exists between share prices (capital) and profitability. Berger [19] argues that there is a positive relationship between a bank's profitability and its level of capital.

\section{Analytical Method and Material}

This study is limited to Afriland First Bank Cameroon for the period 2009 to the period 2016 inclusive. The paper made used of secondary data collected extracted from the consolidated financial statements of Afriland First Bank. This is because of the availability of data within this time period and also given some policy changes which the bank had put in place. The study adopted the causal design because it enabled us to determine 'how' and 'why' the dependent variable changed due to variations in the explanatory variable. The data used in this research was quantitative data.

This study used a model which was adopted from the CAMEL model of 1979 in examining the effect of bank specific factors on the performance of Afriland Bank Cameroon. The choice of the variables is guided by the Signaling theory, the modern portfolio theory and the economics of scale theory with other empirical research. Hence the model can be represented as follows:

$$
\pi_{\mathrm{t}}=\beta_{0}+\beta_{1} \mathrm{CA}_{\mathrm{t}}+\beta_{2} \mathrm{LQ}_{\mathrm{t}}+\beta_{3} \mathrm{ME}_{\mathrm{t}}+\beta_{4} \mathrm{AQ}_{\mathrm{t}}+\mu_{\mathrm{t}}
$$

Where; $\pi$ represent performance of bank at time $t$, expressed by ROA, CA is the capital adequacy of the bank at time $t$, LQ is liquidity Management of the bank at time $t, \mathrm{ME}$ is the management efficiency of the bank at time $t, \mathrm{AQ}$ is asset quality of the bank at time $t . \beta_{0}$ is the Intercept. $\beta_{1}$ to $\beta_{4}$ represent the parameters of the regressors, $\mu$ is the error term, $t$ represent Time period (Table 1).

This study makes use of the Generalized Method of Moments (GMM) in the estimation of the parameters of our specified model. GMM estimation has been used in this study because of its, large sample properties that facilitate comparison. Such estimators are asymptotic efficiency. The method also provides a natural way to conduct tests which take account of both sampling and estimation error. Also its estimators can be constructed without specifying the full data generating process. This characteristic has been exploited in analyzing partially specified economic models in the studying of mixed-specified dynamic models designed to match target moments, and in constructing stochastic discount factor models that link asset pricing to sources of macroeconomic risk. The GMM modifies the strategy of minimizing the generalized least squares as it is in the case with the use of the Ordinary Least Squares technique. It also minimizes the weighted sum of the squared deviations in which the weights reflect the variances and the covariances of the variables. Also the GMM provides a consistent estimator, and its weighting scheme is more efficient than the simpler of the unweighted scheme. GMM provides a powerful tool for finding consistent estimators in models that are otherwise mathematically cumbersome.

Therefore, the validity of the estimated coefficients of our parameters are conducted based on testing the stationarity properties of the time series data using conventional unit root tests such as the Augmented Dickey and Fuller (ADF) test of (1979) and the confirmatory Phillips Perron (PP) test of (1988).

\section{Presentation and Discussion of Results}

Prior to the estimation of eqn. (1), the characteristics of the data have to be examined. The essence is to determine whether the data are stationary (i.e., whether they have unit roots) and their order of integration. We start by examining the graphs of the varaibles to determine whether the variables have trends and if such trend exhibits random walk with drift or without drift. Due to space the graphs are not presented in this work. However, the graphs indicate a stochastic trend with drifts. In this regard, the Augmented Dickey-Fuller (ADF) and Phillips Perron (PP) tests are used to test for stationarity of the variables and order of integration. The results of the stationary tests with intercept or constant term are presented (Table 2).

The result on Table 2 indicates that all the variables used in the study are stationary at levels and therefore integrated of order zero. This implies that our regression model is not spurious. The Unit Circle test not presented because of space indicated that the residuals of the model are all integrated. As such the variables in the models are cointegrated which implies that they exist long run relationships between them (Table 3). The results explain the bank performance equation using the generalised methods of moment. From it we can observe that the coefficient of multiple determination (adj-R-square) is 0.68 . This shows that the variation of Afriland bank performance is more than 68 percent accounted for by variations in capital adequacy, asset quality, management efficiency and liquidity management and less than 38

\begin{tabular}{|c|c|c|c|}
\hline Variable & Unit of Measurement (ratio) & Apriori & Source of data \\
\hline $\begin{array}{l}\text { Return on Asset } \\
\text { (ROA) }\end{array}$ & Net income/Average Total Assets & & $\begin{array}{c}\text { Annual reports } \\
(2009-2015)\end{array}$ \\
\hline Capital Adequacy (CA) & Shareholders' Equity/Total Assets & $\beta_{1}>0$ & $\begin{array}{l}\text { Annual reports } \\
(2009-2015)\end{array}$ \\
\hline Liquidity Management(LQ) & Total Loan/Customers' deposits & $\beta_{2}<0$ & $\begin{array}{c}\text { Annual reports } \\
(2009-2015)\end{array}$ \\
\hline Management Efficiency (ME) & Operating Profit/Net Income & $\beta_{3}>0$ & $\begin{array}{c}\text { Annual reports } \\
(2009-2015)\end{array}$ \\
\hline Asset Quality (AQ) & Loans Loss Provisions/Total Assets & $\beta_{4}>0$ & $\begin{array}{l}\text { Annual reports } \\
(2009-2015)\end{array}$ \\
\hline
\end{tabular}

Source: Researcher (2017).

Table 1: Measurability of the variables. 


\begin{tabular}{|c|c|c|c|c|c|}
\hline Variables & ADF Test Statistics & PP Test Statistics & $\mathbf{1 \%}$ critical Value & $\mathbf{5 \%}$ critical Value & $\mathbf{1 0 \%}$ critical Value \\
\hline ROA & -3.9512 & -3.9512 & -3.7529 & -2.9980 & -2.6387 \\
\hline LQ & -4.8874 & -2.8874 & -3.7529 & -2.9980 & -2.6387 \\
\hline ME & -5.6206 & -12.0825 & -3.7529 & -2.9980 & -2.6387 \\
\hline AQ & -8.5417 & -5.1896 & -3.7529 & -2.9980 & $-1(0)$ \\
\hline CA & -20.1700 & -3.0373 & -3.7529 & -2.9980 & -2.6387 \\
\hline
\end{tabular}

Source: Computed by the author (2017).

Table 2: Unit roots test.

\begin{tabular}{|c|c|c|c|c|}
\hline Variable & Coefficient & Std. Error & t-Statistic & Prob. \\
\hline CA & -0.524434 & 0.010103 & -51.90629 & 0 \\
\hline LQ & -0.010282 & 0.000705 & -14.57782 & 0 \\
\hline ME & 0.001758 & 4.962305 & 35.43885 & 0 \\
\hline AQ & -0.798443 & 0.034086 & -23.42454 & 0 \\
\hline C & 0.063322 & 0.001112 & 56.93707 & 0 \\
\hline $\begin{array}{c}\text { R-squared } \\
\text { Adjusted } \\
\text { R-squared }\end{array}$ & 0.74139 & \multicolumn{2}{|c|}{ F-statistics } & 13.61745 \\
\hline Durbin Watson stat & 2.686942 & \multicolumn{2}{|l}{ Prob (F-stats) } & 0.000021 \\
\hline
\end{tabular}

Source: Computed by the author (2017).

Table 3: Regression result.

percent is explained by the stochastic term. The probability F-statistics shows that our overall result is significant at 1 percent. The calculated D.W of 2.18 which is greater than its critical value at one percent level shows that the results do not suffer from any autocorrelation. As such the results are reliable and could be used for forecasting and policy recommendations.

Capital adequacy, liquidity management and asset quality indicate that they negatively affect the performance of Afriland First Bank Cameroon. This denotes that an increase in any of these variables will reduce the performance of Afriland First bank. The negative significant influence of capital adequacy goes to support the fact that lower capital adequacy ratios encourage the bank to make riskier investments and thus expect higher returns whereas higher ratios reduce risks and thus profits. In another light, lower equity to asset ratios may lead to an increase in debt financing by the bank which is riskier and may lead to future increase in profits. This finding was consistent with findings of Aremu et al. [14]. The negative significant effect of liquidity management on Return on Asset of AFB was due to an increasing loan to deposit ratio. This implies that the First Bank issued out a great number of loans from customers' deposits rather than outside borrowing. This reduced the bank's liquidity level and generated more profits from the interest charged on loans given out. This is in line with the study of Sufian and Habibullah [13] and Baral [20]. Again, the inverse relationship between asset quality and ROA (a proxy for bank performance) of Afriland First Bank is consistent with the-risk return concept whereby riskier investments (increasing loan loss provisions and non-performing loans- poor asset quality) are rewarded with higher returns-profits and less risky investments-good asset quality are rewarded with lower returns-profits.

Management efficiency was found to be positively related to ROA. This was due to the fact that, the bank laid much emphasis on its core activities during the period of study. Specifically, the First bank improved on the quality, the variety and the flexibility of the various financial services and products available for its customers. By focusing on its core activities, the bank was able to generate enough income. These finding is consistent with the findings of Kusa [21]. The finding equally concorded with the theory of economies of scale whereby the bank gained cost advantage by providing a variety of services from which it makes more profits.

\section{Recommendations and Conclusion}

It was observed that during the period of study Afriland was highly leveraged. Even though high leverage had a significant positive effect on Return on Assets, our humble contribution for the bank is that it mitigates the possible negative effects which high leverage can have on the bank in future. For instance, Afriland First Bank can diversify its sources of finance by issuing shares. Nevertheless, if AFB is highly geared, it is due to the nature of the financial system of Cameroon which is bank-based. Afriland may not get other alternative sources of finance. In this light, our humble recommendation to the regulatory bodies of the MINFI and the FMC is that they should awaken the already existing Douala Stock Exchange by making it more accessible to more companies owned by Cameroonians.

We found that during the period of study, liquidity management had a negative influence on the return on assets of Afriland. This implied that the more the bank is liquid due to increasing deposits, the more the return on assets will decrease. Consequently, Afriland First Bank should control their level of deposits so as to minimize the effect of high liquid levels on the bank profitability. Also another measure to limit the negative influence of liquidity management on profitability could be to issue out part of loans from its deposits and another part should be issued through debt financing.

Furthermore, the research highlighted that Afriland First Bank's asset quality had a significant indirect relationship with ROA. This implies that during the period of study, Afriland had an increasing loan loss provision which affected its asset quality negatively. However, beyond expectation, the fall in asset quality led to an increase in profits. Nevertheless, our humble suggestion is that the bank should avoid taking many risks. Even if the bank's behavior towards risk is risk taking with the expectation of higher returns, the bank should diversify its assets in order to avoid unforeseen losses in future. To add, the bank should adopt more efficient and flexible credit management tools such as credit scoring, KYC policy to maximize profits.

\section{References}

1. Flamini C, Valentina C, McDonald G, Liliana S (2009) The Determinants of Commercial Bank Profitability in Sub-Saharan Africa. IMF Working Paper, pp: 1-32.

2. Kouassi A, Akpapuna J, Soededje H (2007) An overview of the banking sector in Cameroon. Journal of Economics and Finance 33: 9-15.

3. Kasekende L (2009) The impact of Global Financial crisis on Africa. Addis Ababa: UNDP.

4. African Development Bank (2009) Africa and the global economic crisis. Dakar African economic outlook.

5. Banking Commission of Central African States (COBAC) (2009) Bank capitalization reforms. Yaoundé: Banking Commission of Central African States.

6. Abdul Jamal A, Abdul Karim M, Hamidi M (2012) Determinants of commercial banks' return on asset: Panel evidence from Malaysia. International Journal of Commerce, Business and Management 1: 2319-2828.

7. Rosman R, Norazlina G, Zainol Z (2014) Efficiency of Islamic banks during the financial crisis: An analysis of Middle Eastern and Asian countries. Pacific Basin Finance Journal 28: 76-90 
Citation: Mbella ME, Magloire AA (2017) The Effect of Bank Specific Factors on the Performance of Afriland First Bank in Cameroon. J Bus Fin Aff 6: 305. doi: 10.4172/2167-0234.1000305

8. Afriland First Bank (2011) Annual Report. Cameroon: Afriland First Bank.

9. Sufian F, Chong RR (2008) Determinants of Bank Profitability in a Developing Economy: Empirical Evidence from Philippines. Asian Academy of Management Journal of Accounting and Finance 4: 91-112.

10. Anjichi DA (2014) Effects of asset and liability management on the financial performance of commercial banks in Kenya. School of Business, University of Nairobi, pp: 1-64

11. Magweva R (2016) Bank specific factors and bank performance in the multicurrency era in Zimbabwe. African Journal of Business Management 10: 373-383.

12. Mahmud K, Mallik A, Imtiaz F, Tabassum N (2016) The Bank-Specific Factors Affecting the Profitability of Commercial Banks in Bangladesh: A Panel Data Analysis. International Journal of Managerial Studies and Research 4: 67-74.

13. Sufian F, Habibullah MS (2015) Determinants of bank profitability in a developing economy: Empirical evidence from Bangladesh. Journal of Business Economics and Management 10: 207-217.

14. Aremu M, Ekpo I, Mustapha A (2013) Determinants of banks' profitability in a developing economy: Evidence from Nigerian banking industry. Interdisciplinary Journal of Contemporary Research in Business 4: 155-181.
15. Wasiuzzaman S, Tarmizi HAA (2010) Profitability of Islamic banks in Malaysia: An Empirical Analysis. Journal of Islamic Economics, Banking and Finance 6: 53-68.

16. Olalekan A, Adeyinka S (2013) Capital adequacy and banks' profitability: An Empirical evidence from Nigeria. American International Journal of Contemporary Research 3: 87-93.

17. Obamuyi TM (2013) Determinants of bank profitability in Nigeria. Organizations and Markets in Emerging Economies 4: 7-109.

18. Abduh M, Idrees $Y$ (2013) Determinants of Islamic banking profitability in Malaysia. Journal of Basic and Applied Sciences 7: 204-210.

19. Berger AN (1995) The relationship between capital and earnings in banking Journal of Money, Credit and Banking 27: 432-456.

20. Baral KJ (2005) Health Check-up of Commercial Banks in the Framework of CAMEL: A Case Study of Joint Venture Banks in Nepal. The Journal of Nepalese Business Studies 8: 211-298.

21. Kusa G (2011) Determinants of financial Performance of Commercial Banks in Kenya. Journal of Economics 6: 7-16. 